DOI: https://doi.org/10.32838/2523-4803/70-4-25

удК 332.024

\title{
Пістунов I.M.
}

доктор технічних наук, професор,

Національний технічний університет «Дніпровська політехніка»

Малахова М.Д.

аспірантка кафедри економіки та економічної кібернетики,

Національний технічний університет «Дніпровська політехніка»

\section{Pistunov Igor, Malahova Maria}

National Technical University «Dnipro Polytechnic»

\section{ВИЗНАЧЕННЯ МІРИ РИЗИКОВАНОСТІ КЛІЕНТА}

\begin{abstract}
У статті розроблено методику визначення міри можливого збитку, який може надати виробничому підприємству новий клієнт. Із иією метою пропонується використати статистику попередніх замовлень, побудувати модель рівня збитку, щзо його може надати клієнт, якщзо відмовиться від замовлення, та порівняння можливого збитку з обсягом обігових коштів підприємства. Статистичні дослідження дадуть змогу розбити всіх клієнтів, щя завдали збитку підприємства, на групи. Таке розбиття, тобто кластеризація, дасть змогу створити роздільні функиії. Тепер під час укладення договору з новим клієнтом можна одразу визначити, до якого класу можливих збитків його можливо віднести. Порівняння можливого обсягу збитків із поточним рівнем обігових коштів дасть змогу керівництву підприємства прийняти рішення щзодо можливості укладення договорів на виконання замовлення.
\end{abstract}

Ключові слова: статистика завдання збитків клієнтами, кластеризація, обігові кочти, економікоматематична модель, роздільні функиії.

Постановка проблеми. У сучасних економічних умовах України економічна чи політична ситуація змушує підприємства скорочувати або й навіть згортати виробництво, а якщо взяти аграрні фірми, то до інших проблем в них додається ще ситуація з недоотриманням прибутку внаслідок неврожаю. У зв'язку із цим виникають проблеми у виробничих підприємств, що укладають договори на виготовлення та встановлення обладнання, бо досить значна кількість замовників їхньої продукції відмовляється від продовження контракту. Така відмова завдає збитків підприємству, адже вже витрачені кошти на розроблення конструкції, проєктування місця розташування готового виробу, закупівлю необхідних матеріалів та комплектуючих.

Аналіз останніх досліджень і публікацій. Основний напрям досліджень вітчизняних авторів спрямований на менеджмент стосунків із клієнтами. Для цього даються словесні поради, як із ним себе поводити, як контролювати їхню діяльність, щоб не допустити зриву виконання фінансових зобов'язань по контракту. Так, у роботі [1] рекомендується: «Оцінювання ризику клієнта здійснюється за відповідними критеріями, зокрема за типом клієнта, географічним розташуванням держави реєстрації клієнта або установи, через яку він здійснює передачу (отримання) активів, і видом товарів, послуг». При цьому жодних методик розрахунку рівня ризику не подано.

А.В. Лисаков та Д.А. Новіков у статті «Договірні відносини в управлінні проектами» [1] досліджують оптимізаційні моделі відносин у керівництві проєк- тами. Зауважується, що в управлінні проєктами необхідно переглянути відносини із зовнішнім оточенням діяльності підприємства для досягнення кінцевих результатів оптимізації. Загальними завданнями управління є планування, вибір контрагентів, визначення параметрів договірного та оперативного управління.

Результати встановлення і вирішення цих завдань свідчать про те, що математичне моделювання являє собою ефективний інструмент аналізу та синтезу механізмів управління у договірних відносинах. Напрямом роботи є інтеграція результатів моделювання у сучасні програмні середовища для оптимізації управління договорами.

Отже, пошук рішення для зміни роботи з клієнтом під час управління проєктами є важливою частиною роботи підприємства, оптимізація якої є необхідною у роботі підприємства 3 клієнтами.

Джон Форман у книзі «Багато цифр» наголошує, що необхідно використовувати дані своїх клієнтів, щоб краще їх знати [2]. Треба розробляти клієнтські бази та знаходити найкращі рішення для фірми. Один зі способів цього досягти - використати кластеризацію для сегментування ринку клієнтів, зібрати різні параметри i розділити їх на групи. Робота з групами допомагає визначити, що у іiі членів однакове, а що відрізняє їх один від одного. Ці знання допоможуть виконати оптимізацію рішень.

Формулювання цілей статті. Метою роботи є розроблення надійної методики, яка б дала змогу мінімізувати ризики під час визначення цінності нових 
замовлень через фактори, які можуть бути зібрані на початковому етапі роботи з клієнтом.

Виклад основного матеріалу. Для реалізації поставлених завдань було розроблено методику визначення міри можливого збитку, який може надати виробничому підприємству новий клієнт.

Для цього пропонується дотримуватися такого алгоритму:

1. Використати статистику попередніх замовлень, в яких клієнт відмовився від продовження контракту і не оплатив витрати підприємства, яке виконувало замовлення на виготовлення та встановлення конструкції.

2. Побудувати таблиці рівня збитку, що його може надати клієнт, якщо відмовиться від замовлення, що полягає у складенні таблиці, яка, крім рівня збитку, містить у собі характеристики фірми-замовника, такі як відстань до клієнта, вік керівника фірми-замовника, сума контракту, дата укладання договору про виготовлення конструкції, валюта балансу замовника.

3. Використати алгоритм кластеризації шляхом розбиття всіх клієнтів, які завдали збитки на класи, знайти середній рівень збитку для кожного класу.

4. Розрахувати коефіцієнти лінійних роздільних функцій.

5. Укладати договір із новим клієнтом шляхом підстановки в роздільні функції даних клієнта. Роздільна функція, яка прийме найбільше значення, й означає, до якого класу віднесено нового клієнта.

6. Порівняти можливий обсяг збитків із поточним рівнем обігових коштів, що дасть змогу керівництву підприємства прийняти рішення щодо можливості укладення договорів на виконання замовлення.

Запропонований алгоритм було використано для аналізу та прогнозування збитковості клієнтів ТОВ «МТК Україна», основна діяльність якого - виготовлення ангарів із гофрованого металу та їх монтаж на території клієнтів, серед яких більшість становлять агрофірми.

У табл. 1 наведено фрагмент даних відмов за чотири роки діяльності фірми за такими характеристиками:
- Дата договору (або попередня згода) та дата відмови.

- Господарська діяльність замовника.

- Площа фірми замовника.

- Область, в якій планувалося будівництво.

- Відстань до замовника.

- Кількість працівників.

- Вік замовника.

- Статутний капітал.

- Рік заснування.

- Розмір ангара.

- Етап, на якому було припинене будівництво.

- Збитки, до яких призвела відмова.

Загалом було зібрано 27 подібних випадків.

Для групування даних із табл. 1 було використано кластерний аналіз, який призначений для об'єднання деяких об'єктів в групи (кластери) так, щоб в один клас потрапляли максимально схожі об'єкти, а об'єкти різних класів максимально відрізнялися один від одного. Усі кластерні алгоритми потребують оцінки відстаней між кластерами або об'єктами. Для даного розрахунку було прийнято евклідів метод відстаней [4].

Проведений у програмі Excel кореляційний аналіз впливу економічних чинників на збитки показав, що найбільш впливовими $є$ такі: $x_{1}$ - площа землі замовника, $x_{2}-$ відстань до замовника, $x_{3}-$ вік особи, що приймає рішення, $x_{4}-$ рік заснування фірми-замовника, $x_{5}$ - висота ангара, $x_{6}$ - довжина ангара.

Наступним етапом було розбиття на кластери всіх даних відмов. Треба було зрозуміти, чи формують замовники, які відмовилися від будівництва, кластери, які можуть бути осмислені. Спочатку для цього використовувалася ієрархічна класифікація пакету STATISTICA. Згідно із цим алгоритмом, кожний елемент об’єднується, і формуються кластери. Кожен вузол діаграми являє собою об'єднання двох або більше кластерів, положення вузлів на вертикальній осі визначає відстань, на якій були об’єднані відповідні кластери.

Таблиця 1

Характеристика відмов

\begin{tabular}{|c|c|c|c|c|c|c|c|c|c|c|c|c|}
\hline 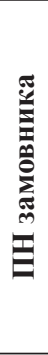 & 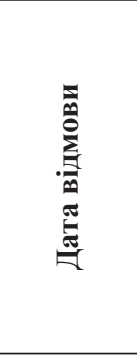 & 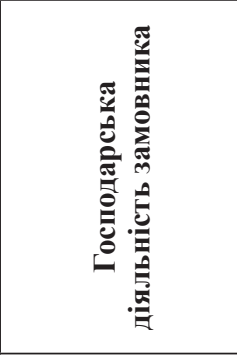 & 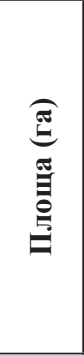 & 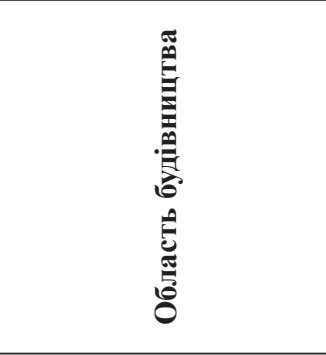 & 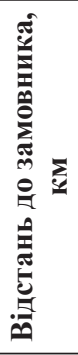 & 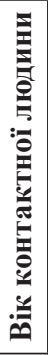 & 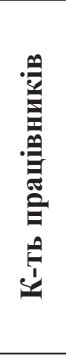 & 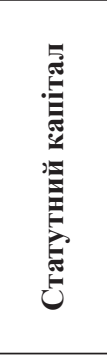 & 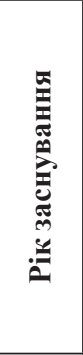 & 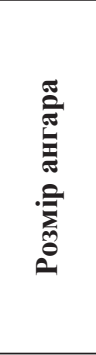 & 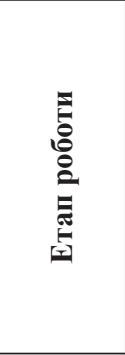 & 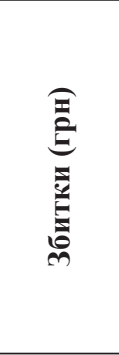 \\
\hline 1 & $\begin{array}{l}15.02 .19 / \\
20.08 .19\end{array}$ & $\begin{array}{l}\text { Зернові } \\
\text { та технічні } \\
\text { культури }\end{array}$ & 4800 & $\begin{array}{c}\text { Кіровоградська обл., } \\
\text { Оникієве }\end{array}$ & 299 & 60 & 62 & 7400 & 1936 & $20 / 70$ & Метал & 1000200 \\
\hline 2 & $\begin{array}{l}10.11 .18 / \\
16.07 .19\end{array}$ & $\begin{array}{l}\text { Оптова торгівля } \\
\text { продуктами } \\
\text { харчування } \\
\end{array}$ & 100 & $\begin{array}{c}\text { Дніпропетровська обл., } \\
\text { Чумаки }\end{array}$ & 39,9 & 48 & 8 & 9375 & 1997 & $20 / 50$ & Договір & 4800 \\
\hline 3 & $\begin{array}{l}27.05 .19 / \\
24.06 .19\end{array}$ & $\begin{array}{l}\text { Зернові } \\
\text { культури }\end{array}$ & 3000 & $\begin{array}{c}\text { Дніпропетровська обл., } \\
\text { Васильківка }\end{array}$ & 112 & 53 & 154 & 340000 & 2004 & $18 / 50$ & Договір & 5600 \\
\hline
\end{tabular}


Таблиця 2

\begin{tabular}{|c|c|c|c|c|c|c|}
\hline \multirow{2}{*}{$\begin{array}{l}\text { Cluster } \\
\text { Number }\end{array}$} & $\begin{array}{l}\text { Distances b } \\
\text { Squared dis }\end{array}$ & $\begin{array}{r}\text { Відста } \\
\text { w diagona } \\
\text { ices above }\end{array}$ & $\begin{array}{l}\text { i між кла } \\
\text { liagonal }\end{array}$ & герами & & \\
\hline & No. 1 & No. 2 & No. 3 & No. 4 & No. 5 & No. 6 \\
\hline No. 1 & 0,000000 & 4,874973 & 5,040394 & 4,959037 & 12,57932 & 6,050414 \\
\hline No. 2 & 2,207934 & 0,000000 & 1,112081 & 0,919211 & 5,29785 & 1,691196 \\
\hline No. 3 & 245082 & 1,054552 & 0,000000 & 0,900388 & 3,60699 & 1,015714 \\
\hline & & & & & & 0,859874 \\
\hline 0.5 & 3,5467 & 2,3017 & 1,899208 & & 0,00000 & 2,908145 \\
\hline Jo. 6 & 2,459759 & 1,300460 & 1,007826 & 0,927294 & 1,70533 & 0,000000 \\
\hline
\end{tabular}

Для перевірки припущення, що дані формують шість кластерів, розіб'ємо дані методом $K$-середніх на шість кластерів і перевіримо значимість відмінностей між отриманими групами [5]. Метод $K$-середніх обчислюється, починаючи з k випадково вибраних спостережень, які стають центрами груп, після чого об'єктний склад кластерів змінюється 3 метою мінімізації змінності всередині кластерів і максимізації змінності між кластерами.

Кожне наступне спостереження $(K+1)$ відноситься до тієї групи, міра подібності із центром тяжкості якого є мінімальною. Після зміни складу кластера обчислюється новий центр ваги, найчастіше як вектор середніх по кожному параметру [6].

За результатами кластеризації було утворено чотири групи замовників, що відмовилися від продовження контракту: до першого кластера відносяться замовники, які мають середню за площею землю, до другого кластера можна віднести найзбитковіших замовників, до третього кластера належать замовники, які мають найбільші за площею землі, до четвертого кластера віднесено будівництво найменших за розмірами ангарів.

Був проведений дисперсійний аналіз для визначення значущості відмінності між отриманими кластерами. Значимість для довірчої ймовірності $p<0,05$ підтверджує значну відмінність між кластерами. Тому всі фактори були вибрані правильно та приймаються.

Отже, на підставі кластеризації простір компонентів складається з чотирьох областей, кожна 3 яких містить точки, що відповідають об'єктам з одного класу. Тепер необхідно розробити алгоритм, який би дав змогу віднести нового клієнта до певного кластера. Завдання розпізнавання нового клієнта може розглядатися як побудова меж областей рішень, які поділяють кластери.

Нехай ці межі визначаються роздільними $Y$-функціями [7]. Вони допомагають визначити, чи належить об'єкт кластеру. Тобто необхідно виконати умови так званої компактності, коли кожний вектор ознак кластерів, що належать одному класу, утворює в просторі опису локально обмежену область. Якщо кластери, які відповідають різним кластерам, рознесені досить далеко один від одного, то можна скористатися простими схемами розпізнавання. Наприклад, класифікація об' єкта за відстанню від центра ваги кластерів або за середньою відстанню до всіх елементів вибірки відповідних їм центрів.
На формування збитків підприємства впливає шість різних факторів. Необхідно побудувати регресії для отримання коефіцієнтів роздільних функцій аналогічно методиці, описаній у [8]. На основі отриманих кластерів було побудовано роздільні функції за допомогою додаткової змінної $Y_{i}$, яка під час розрахунків лінійної регресії приймала значення 1000 для одного кластера та 0 для інших. Розрахунок проводився за допомогою програми Excel. Загалом регресія проводилася чотири рази для чотирьох кластерів. Для мінімізації ризиків раптових відмов на основі лінійної регресії були складені рівняння лінійних роздільних функцій методом регресійного аналізу [9], що мають вигляд:

$Y_{1}=-0,12+0,19 x_{1}+0,12 x_{2}+0,05 x_{3}-0,51 x_{4}+0,16 x_{5}-0,24 x_{6}$, $Y_{2}=-0,10+0,24 x_{1}+0,32 x_{2}+0,15 x_{3}-0,53 x_{4}+0,23 x_{5}-0,30 x_{6}$, $\mathrm{Y}_{3}=-0,04+0,24 x_{1}+0,26 x_{2}+0,09 x_{3}-0,52 x_{4}+0,24 x_{5}-0,28 x_{6}$, $Y_{4}=0,06+0,13 x_{1}+0,26 x_{2}+0,19 x_{3}-0,55 x_{4}+0,09 x_{5}-0,27 x_{6}$,

Варто відзначити, що регресійний аналіз проводився для нормованих даних.

Таким чином, отримано функції залежності збитку від кожного кластера відмов замовників залежно від факторів $x_{1}, x_{2}, x_{3}, x_{4}, x_{5}, x_{6}$. Коефіцієнт апроксимації $\mathrm{R}^{2}$ для кожної регресії $є$ прийнятним [9], а стандартна помилка $\epsilon$ порівняно малою. Ці функції є роздільними у визначеності кластера і можуть бути використані для майбутніх вхідних даних. Таким чином, можна виявити замовлення, які будуть відноситися до кластерів із різними рівнями ризику: найзбитковіші замовлення великих ангарів великими підприємствами, заснованих у 2000-ні роки, найзбитковіші замовлення середніх за розмірами підприємств, найменші за збитками замовлення великих за розмірами підприємств та найменші за збитками замовлення найменших ангарів середніми за розмірами підприємств.

Наприклад, для розрахунку були взяті такі дані замовника, який щойно звернувся до фірми $з$ метою побудувати ангар розміром 18/50 (табл. 3).

Таблиця 3

Вхідні дані

\begin{tabular}{|c|c|c|c|c|c|c|}
\hline & $\boldsymbol{X}_{\mathbf{1}}$ & $\boldsymbol{X}_{\mathbf{2}}$ & $\boldsymbol{X}_{\mathbf{3}}$ & $\boldsymbol{X}_{\mathbf{4}}$ & $\boldsymbol{X}_{\mathbf{5}}$ & $\boldsymbol{X}_{\mathbf{6}}$ \\
\hline Замовник 1 & 5000 & 443 & 60 & 2003 & 18 & 50 \\
\hline
\end{tabular}

Спочатку треба дізнатися, до якої ризикової групи входить клієнт, щоб визначити, чи доцільно для фірми 
приймати замовлення. Підставимо ці дані в роздільні функції й отримаємо такі результати значень розподільних функцій: $Y_{1-} 0,05 ; Y_{2}-0,48 ; Y_{3}-0,42 ; Y_{4}-0,43$.

Зі значень $Y_{\mathrm{i}}$ знаходимо максимальне, до якого входять ці клієнти. У нашому разі замовник входить до другого кластера, до якого входять найзбитковіші замовлення середніх за розмірами підприємств, отже, до найбільш ризикової групи.

Середній збиток, який може отримати фірма під час раптової відмови цього замовлення, дорівнює 564306 грн. Порівняємо ці дані з обіговими коштами фірми на даний момент, які становлять 854 тис грн. Різниця становитиме 289694 грн.

Отже, на цей момент замовлення не рекомендується приймати, бо, по-перше, замовник потрапляє в найбільш ризикову групу 3 кластерів, а по-друге, обігові кошти перевищують середній збиток тільки у 1,5 рази, і за політикою фірми такого запасу коштів замало, оскільки ставить фірму у ризикове становище у найскладніший період для роботи підприємства.

Розроблену програму було запроваджено в бізнесдіяльність фірми «ТОВ «МТК Україна».

Висновки. Таким чином, кластеризація даних дає змогу спочатку виділити, до якої групи ризику належить клієнт, а потім на основі обігових коштів, які дають змогу зрозуміти, чи може фірма дозволити у цей момент ризиковий проєкт, прийняти або відхилити замовлення. Якщо клієнт потрапляє до більш ризикової групи і фірма не має додаткових обігових коштів на ризикове замовлення, то від цього клієнта рекомендується відмовитися. I, навпаки, якщо клієнт потрапляє до менш ризикової групи, фірма може прийняти замовлення. В умовах декількох клієнтів, які приходять одночасно, ця модель є найбільш ефективною для швидкого прийняття рішень.

\section{Список літератури:}

1. Класифікація клієнтів. Оцінка ризиків. URL: https://pidruchniki.com/87222/finansi/klasifikatsiya_rizikiv_kliyentiv_ upravlinnya_rizikami (дата звернення: 19.12.2019).

2. Лысаков А.В., Новиков Д.А. Договорные отношения в управлении проектами. Москва : ИПУ РАН, 2004.100 с.

3. Форман Д. Кластеризации для сегментирования рынка клиентов. URL: http://www.marketing.spb.ru/lib-research/ segment/k-means_cluster_analysis.htm (дата звернення: 19.12.2019).

4. Пістунов I.M., Антонюк О.П., Турчанінова І.Ю. Кластерний аналіз в економіці : навчальний посібник. Дніпропетровськ : Національний гірничий університет, 2008. 84 с.

5. Кластерний аналіз. URL : http://sosninep.blogspot.com/2013/11/statistica-2.html?m=1 (дата звернення: 19.01.2020).

6. Кластерний аналіз у пакеті STATISTICA. URL : http://statsoft.ru/solutions/ExamplesBase/branches/detail.php (дата звернення: 10.11.2019).

7. Фукунага К.М. Нечеткие множества. Москва : Наука, 1979. 368 с.

8. Пістунов I.M., Цуркан I.I. Формування портфеля замовлень машинобудівного підприємства з метою зменшення ризику упущеної вигоди. Технологический аудит и резервы производства. 2015. № 4/5(24). С. 72-75.

9. Пістунов I.M. Економічна кібернетика : навчальний посібник. Дніпро : Нац. гірн. ун-т, 2014. 215 с.

\section{References:}

1. Klasyfikatsiya kliyentiv. Otsinka ryzykiv [Customer classification. Risk assessment]. Available at: https://pidruchniki.com/ 87222/finansi/klasifikatsiya_rizikiv_kliyentiv_upravlinnya_rizikami (accessed 19.12.2019). (in Ukrainian)

2. Lysakov A.V., Novikov D.A. (2004) Dogovornyye otnosheniya v upravlenii proyektami [Contractual relations in project management]. Moscow: IPU RAS, 100 p. (in Russian)

3. Foreman D. Klasterizatsii dlya segmentirovaniya rynka kliyentov [Clustering for customer market segmentation]. Available at: http://www.marketing.spb.ru/lib-research/segment/k-means cluster analysis.htm (accessed 19.12.2019). (in Russian)

4. Pistunov I.M., Antonyuk O.P., Turchaninova I.Y. (2008) Klasternyy analiz v ekonomitsi [Cluster Analysis in Economics]. Dnipropetrovsk: National Mining University. (in Ukrainian)

5. Klasternyy analiz [Cluster analysis]. Available at: http://sosninep.blogspot.com/2013/11/statistica-2.html? m=1 (accessed 19.01.2020). (in Ukrainian)

6. Klasternyy analiz v paketi STATISTICA [Cluster analysis in the STATISTICA package]. Available at: http://statsoft.ru/ solutions/ExamplesBase/branches/detail.php (accessed 10.11.2019). (in Ukrainian)

7. Fukunaga K. (1979) Nechetkiye mnozhestva [Fozzy sets]. Moscow: Science. The Main Edition of Physical and Mathematical Literature. (in Russian)

8. Pistunov I.M., Tzurkan I.I. (2015) Formuvannya portfelyu zamovlen' mashynobudivnoho pidpryyemstva z metoyu zmenshennya ryzyku upushchenoyi vyhody [Formation of an order book of a machine-building enterprise in order to reduce the risk of lost profit]. Technological audit and production reserves, no. 4/5(24), pp. 72-75. (in Ukrainian)

9. Pistunov I.M. (2014) Ekonomichna kibernetyka: navchalnyi posibnyk [Economic Cybernetics: textbook tool]. Dnypropetrovsk, Nat. mines Univ. (in Ukrainian) 


\section{ОПРЕДЕЛЕНИЕ МЕРЫ РИСКОВАННОСТИ КЛИЕНТА}

В статье разработана методика определения степени возможного ущерба, который может нанести производственному предприятию новый клиент. С этой целью предлагается использовать статистику предварительных заказов, построчть модель уровня ущерба, который может нанести клиент, если откажется от заказа, и сравнить возможный ущерб с объемом оборотных средств предприятия. Статистические исследования позволят разбить всех клиентов, которые нанесли ущерб предприятию, на группь. Такое разбиение, то есть кластеризация, позволит создать раздельные функичии. Теперь при заключении договора с новым клиентом можно сразу определить, к какому классу возможных убытков его можно отнести. Сравнение возможного объема убытков с текущим уровнем оборотных средств позволит руководству предприятия принять решение о возможности заключения договоров на выполнение заказа.

Ключевые слова: статистика нанесения ущеерба клиентами, кластеризация, оборотные средства, экономико-математическая модель, раздельные функции.

\section{DETERMINATION OF THE CUSTOMER RISK MEASURE}

The authors of the article identified the problem of manufacturing enterprises in that a significant number of customers of their products refuses to extend the contract. This refusal is detrimental to the enterprise, since the funds have already been spent on designing the design, designing the location of the finished product, purchasing the necessary materials and components. Therefore, a method was developed to determine the extent of the potential loss that could give a manufacturing company a new client. For this purpose it is proposed to use statistics of pre-orders in which the client refused to extend the contract and did not pay the costs of the company that executed the orders for the manufacture and installation of the structure. Building a model of the level of damage that can be provided by the client, if he refuses the order, consists of stacking tables, which in addition to the level of damage includes the characteristics of the client company, such as the distance to the client, the age of the head of the client firm, the amount of the contract, date conclusion of the contract on production of a design, currency of balance of the customer. The table allows you to use a clustering algorithm that was implemented using Statistica software. The breakdown of all customers who have suffered damage to classes makes it possible to find the average level of damage for each class. According to the results of clustering, the coefficients of linear separation functions were calculated. Now, when concluding a contract with a new client, you can immediately determine which class of possible losses can be attributed. For this purpose, the client data is substituted into all separate functions. The split feature that takes the most value and indicates which class the new client is assigned to. Comparison of the possible volume of losses with the current level of working capital will allow the management of the enterprise to decide on the possibility of concluding contracts for the execution of the order. In order to automate the calculations, an interpreted Python object-oriented programming language was used and its standard library, Tkinter, to create a user interface. The developed program was introduced into the business activities of the company "MTK Ukraine".

Key words: statistics of customer loss task, clustering, working capital, economic-mathematical model, separate functions. 